\title{
昏睡患者聴性脳幹反応の経時的観察
}

\author{
馬場 俊吉・八木 聰明・青木 秀治 \\ 佐久間文子・山口＼cjkstart潤

\section{Changes in the Auditory Brain-stem Response in Comatose Patients}

\author{
Shunkichi Baba, Tosiaki Yagi, Hideharu Aoki, \\ Ayako Sakuma and Jun Yamaguchi \\ (Nippon Medical School)
}

The auditory brain-stem response (ABR) was correlated with age, cause of coma and prognosis in 157 comatose patients. It was found that changes in the ABR could not be attributed to the age or cause of coma. In the patients who recovered and the persistent vegetative state the one to five inter wave latency became shorter. In the patients who later died, the one to five inter wave latency was prolonged. The patients who showed no response or only wave one from the beginning of coma and those in whom the wave form increased with the latency all died. These findings suggest that the ABR may be important test for judging the prognosis in comatose patients.

Key words: ABR, coma, prognosis

はじめに

聴性脳幹反応（A B R）は, 被検者の意識状 態や麻酔などには影響を受けにくく安定した反 応で脳幹の機能をよく反映することが知られて (る ${ }^{12)}$. そのため, AB Rが意識障害者の脳 幹の状態や患者の状態を観察する上に有用な検 查法となりつつある．特に A B R を経封的に記 録することにより，意識障害の程度や脳幹の 状態やその変化を知るととが可能となってき た ${ }^{3)}$. また，深昏睡患者の予後や脳死の判定を 行う為にAB Rによる脳幹機能の把握は重要な 手段であると考えられる(4)5. しかし，昏睡に 陷った原因や疾患がA B R に影響を及ぼすか否
かの検討はなされていない.一方，年齢や男女 差により AB Rの I-V波間潜時に差が生じる ことが知られている，乙のため，乳幼児にお的 る聴力検査や精神発達遅滞の検査として A B R を使用する際には, 年齢による変化を考慮する 必要がある，そこで，昏睡患者のABRを出来 うるかぎり経時的に観察し年齢及び昏睡の原因 疾患がA B R に影響を与えるか否かの検討を行 い, 合せて昏睡患者の予後判定としてAB Rの 有用性について検討した。

\section{対象および方法}

日本医科大学付属病院救命救急センターに緊 急入院した，5ケ月から80才（平均年齢 41.3 
才）までの男性 117 例, 女性 40 例の昏睡患者 157 例を対象とした。昏睡の程度は，ほとんど の症例が自発運動が全く認められず, 痛み刺激 にも全く反応しない深昏睡で，一部，強度の痛 み刺激には多少の反応を示す症例を含んだ。

A B Rは, 三栄測器, シグナル・プロセッサ ー7 S11を用いて測定した。検査音は, 駆動 パルス幅 $100 \mu \mathrm{sec}$ の矩形波で $100 \mathrm{~dB} \mathrm{SPL}$

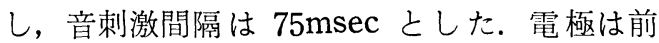
額部を陽極に，検查側耳乳突部を陰極とし，反 対側耳乳突部を接地とした。周波数濾過は, 80 から $1200 \mathrm{~Hz}$ とした. 1 回の测定は2048回加 算し， 2 回以上の記録を行い，できうるかぎり 経時的に観察を行った。 また，ABRの測定 は, 昏睡に陷ってから48時間以内に開始した。

\section{結 果}

昏睡患者 157 例の年齢分布は, 0 〜 才が 16 例，10〜19才が20例，20〜29才が14例，30〜39 才が15例，40〜49才が24例，50〜 59才が30例, 60〜69才が 21 例, 70〜 79才が 14 例, 80 才以上が 3 例であった。

昏睡に陷った原因筷患は，脳内出血が最も多 く50例, 次いでクモ膜下出血26例, 硬膜下出血 19例, DOA (Dead On Arrival) 19例, 脳挫 傷および脳浮腫15例, cardiac arrest 5 例, その他23例であった。

年齢，原因疾患と A B R の関係をみると表 1，2のように，0～9才ではDOAが最も多 く, 16例中 8 例に認められた。 乙の年代の D O $\mathrm{A}$ 初回 A B Rでは I 波のみ 3 例， I-V波間潜

表１ 年齢による原因疾患の違いと予後

\begin{tabular}{|c|c|c|c|c|c|c|c|c|}
\hline 年齢 & 予後 & $\begin{array}{l}\text { 脳内 } \\
\text { 出血 }\end{array}$ & 硬膜下 & $\begin{array}{l}\text { クモ膜 } \\
\text { 下出血 }\end{array}$ & $\begin{array}{l}\text { 他他の } \\
\text { 頭蓋内出血 }\end{array}$ & $\mid$ 脳浮腫 & D O A & その他 \\
\hline $0 \sim 9$ & $\begin{array}{l}\text { 回復 } \\
\text { 植物 } \\
\text { 死亡 }\end{array}$ & $\begin{array}{l}1 \\
1\end{array}$ & 1 & 1 & 1 & 1 & $\begin{array}{l}2 \\
1 \\
5\end{array}$ & 2 \\
\hline $10 \sim 19$ & $\begin{array}{l}\text { 回復 } \\
\text { 植物 } \\
\text { 死亡 }\end{array}$ & $\begin{array}{l}1 \\
3\end{array}$ & 4 & 2 & 1 & $\begin{array}{l}2 \\
1 \\
1\end{array}$ & 1 & 4 \\
\hline $20 \sim 29$ & $\begin{array}{l}\text { 回復 } \\
\text { 植物 } \\
\text { 死亡 }\end{array}$ & $\begin{array}{l}1 \\
1\end{array}$ & 1 & $\begin{array}{l}1 \\
2 \\
1\end{array}$ & 1 & 1 & $\begin{array}{l}1 \\
2\end{array}$ & 2 \\
\hline $30 \sim 39$ & $\begin{array}{l}\text { 回復 } \\
\text { 植物 } \\
\text { 死亡 }\end{array}$ & $\begin{array}{l}1 \\
1\end{array}$ & $\begin{array}{l}2 \\
1\end{array}$ & $\begin{array}{l}1 \\
2\end{array}$ & 1 & $\begin{array}{l}1 \\
2\end{array}$ & & $\begin{array}{l}2 \\
1\end{array}$ \\
\hline $40 \sim 49$ & $\begin{array}{l}\text { 回復 } \\
\text { 植物 } \\
\text { 死亡 }\end{array}$ & $\begin{array}{l}1 \\
3\end{array}$ & 2 & $\begin{array}{l}1 \\
5\end{array}$ & $\begin{array}{l}4 \\
5\end{array}$ & & & $\begin{array}{l}1 \\
1 \\
1\end{array}$ \\
\hline $50 \sim 59$ & $\begin{array}{l}\text { 回復 } \\
\text { 植物 } \\
\text { 死亡 }\end{array}$ & $\begin{array}{l}2 \\
1 \\
5\end{array}$ & 2 & 4 & $\begin{array}{l}1 \\
1 \\
4\end{array}$ & $\begin{array}{l}1 \\
1 \\
2\end{array}$ & 1 & $\begin{array}{l}2 \\
3\end{array}$ \\
\hline $60 \sim 69$ & $\begin{array}{l}\text { 回復 } \\
\text { 植物 } \\
\text { 死亡 }\end{array}$ & $\begin{array}{l}1 \\
2 \\
2\end{array}$ & $\begin{array}{l}1 \\
2\end{array}$ & $\begin{array}{l}2 \\
3\end{array}$ & & 1 & 1 & $\begin{array}{l}4 \\
2\end{array}$ \\
\hline $70 \sim 79$ & $\begin{array}{l}\text { 回復 } \\
\text { 植物 } \\
\text { 死亡 }\end{array}$ & 1 & $\begin{array}{l}1 \\
2\end{array}$ & & $\begin{array}{l}1 \\
1\end{array}$ & & 5 & $\begin{array}{l}1 \\
2\end{array}$ \\
\hline 80才以上 & $\begin{array}{l}\text { 回復 } \\
\text { 植物 } \\
\text { 死亡 }\end{array}$ & 1 & & 1 & & 1 & & \\
\hline
\end{tabular}


時 $4.4 \mathrm{msec}$ 以上の延長が 4 例，無反応は 1 例 であった。予後は，2例が回復，1例が植物状 態に移行し， 5 例が死亡した. 10～19才では， 外傷性の頭蓋内出血が20例中11例と多く, 同疾 患の初回ABRは，3 例が $\mathrm{I} \sim \mathrm{V}$ 波閒潜時正 常, 延長が 6 例, 無反応は 1 例で, 予後は, 回 復が 6 例, 植物状態が 1 例, 死亡は 9 例であっ た. 20〜29才，30〜39才，40〜49才，50〜59 才，60〜 69才であ同様に頭蓋内出血が最も多く 認められた，20２9才では，14例中 8 例で初回 A B Rには，I-V 波間潜時正常は 2 例，延長 が 5 例, I 波のみ 1 例で, 予後は回復が 1 例, 植物状態が 3 例，死亡は 4 例であった. $30 \sim 39$ 才では15例中 9 例が頭蓋内出血で, 初回 A B R には, I - V 波間潜封正常が 2 例, 延長が 5
例, 無反応は 2 例で予後は回復が 4 例, 植物状 態が 1 例, 死亡は 4 例であった。 40〜49才では 24例中21例が頭蓋内出血で, 初回A B R I $\mathrm{V}$ 波間潜時正常が 5 例, 延長が 10 例, $\mathrm{V}$ 波消失 は 1 例, I 波のみ 3 例, 無反応が 2 例で, 予後 は 6 例が回復, 15例が死亡した. 50〜 59才では 30 例中 20 例が頭蓋内出血で, 初回AB R 波, I $-V$ 波間潜時正常が10例で，延長が 6 例，I 波 のみ 2 例, 無反応は 2 例で, 正常反応が半数に 認められたが, 予後は死亡が16例之多く回復, 植物状態各 2 例であった. 60〜 69才では，21例 中13例が頭蓋内出血で初回の A B R は, I-V 波間潜時正常が 5 例, 延長が 6 例で, I 波のみ 1 例, 無反応は 1 例で, 予後は回復が 4 例, 植 物状態が 2 例, 死亡は 7 例であった。 70〜79才

表 2 A B R と年㱓, 予後の関係

\begin{tabular}{|c|c|c|c|c|c|c|c|}
\hline 年歯命 & 予後 & $\begin{array}{l}4.2 \mathrm{msec} \\
\text { 以 }\end{array}$ & $\begin{array}{r}4.2 \sim 4.4 \\
\text { msec }\end{array}$ & $\begin{array}{l}4.4 \mathrm{msec} \\
\text { 以 } 5\end{array}$ & $\begin{array}{l}\mathrm{V} \text { 波 } \\
\text { 消失 }\end{array}$ & $\begin{array}{l}\mathrm{I} \text { 波 } \\
\text { のみ }\end{array}$ & 無反応 \\
\hline $0 \sim 9$ & $\begin{array}{l}\text { 回復 } \\
\text { 植物 } \\
\text { 死亡 }\end{array}$ & $\begin{array}{l}1 \\
1\end{array}$ & $\begin{array}{l}1 \\
1\end{array}$ & $\begin{array}{l}3 \\
1 \\
1\end{array}$ & & 3 & 4 \\
\hline $10 \sim 19$ & $\begin{array}{l}\text { 回復 } \\
\text { 植物 } \\
\text { 死亡 }\end{array}$ & $\begin{array}{l}4 \\
4\end{array}$ & $\begin{array}{l}3 \\
2\end{array}$ & $\begin{array}{l}2 \\
4\end{array}$ & & 1 & \\
\hline $20 \sim 29$ & $\begin{array}{l}\text { 回復 } \\
\text { 植物 } \\
\text { 死亡 }\end{array}$ & $\begin{array}{l}2 \\
2\end{array}$ & $\begin{array}{l}2 \\
2\end{array}$ & $\begin{array}{l}3 \\
2\end{array}$ & & 1 & \\
\hline $30 \sim 39$ & $\begin{array}{l}\text { 回復 } \\
\text { 植物 } \\
\text { 死亡 }\end{array}$ & $\begin{array}{l}3 \\
2 \\
1\end{array}$ & $\begin{array}{l}3 \\
1\end{array}$ & $\begin{array}{l}1 \\
2\end{array}$ & & & 2 \\
\hline $40 \sim 49$ & $\begin{array}{l}\text { 回復 } \\
\text { 植物 } \\
\text { 死亡 }\end{array}$ & $\begin{array}{l}4 \\
3\end{array}$ & 3 & $\begin{array}{l}3 \\
1 \\
4\end{array}$ & 1 & 3 & 2 \\
\hline $50 \sim 59$ & $\begin{array}{l}\text { 回復 } \\
\text { 植物 } \\
\text { 死亡 }\end{array}$ & $\begin{array}{l}4 \\
2 \\
6\end{array}$ & $\begin{array}{l}1 \\
5\end{array}$ & $\begin{array}{l}1 \\
1 \\
3\end{array}$ & & 3 & 4 \\
\hline $60 \sim 69$ & $\begin{array}{l}\text { 回復 } \\
\text { 植物 } \\
\text { 死亡 }\end{array}$ & $\begin{array}{l}6 \\
1 \\
3\end{array}$ & $\begin{array}{l}1 \\
1\end{array}$ & $\begin{array}{l}1 \\
1 \\
4\end{array}$ & & 1 & 2 \\
\hline $70 \sim 79$ & $\begin{array}{l}\text { 回復 } \\
\text { 植物 } \\
\text { 死亡 }\end{array}$ & $\begin{array}{l}1 \\
3\end{array}$ & $\begin{array}{l}1 \\
2\end{array}$ & $\begin{array}{l}1 \\
2\end{array}$ & & 2 & 2 \\
\hline 80 才以上 & $\begin{array}{l}\text { 回復 } \\
\text { 植物 } \\
\text { 死亡 }\end{array}$ & & & $\begin{array}{l}1 \\
1\end{array}$ & & & 1 \\
\hline
\end{tabular}


では，DOAおよび cardiac arrest が14例い

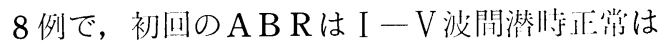
1 例で，延長が 4 例， I 波のみ 1 例，無反忍が 2 例であった，予後は回復が 1 例，死亡は 7 例 であった。

年齢と $\mathrm{I}-\mathrm{V}$ 波間潜時の関係は, 図 1 の如 く, 各年齢層の初回 $\mathrm{ABR}$. 平均 $\mathrm{I}-\mathrm{V}$ 波間潜 時 (標準偏差) では統計学的に80才以上と $10 才$ 代，30才代，50才代，60才代において危険率 5 \%で有意差が認められた。また，最終測定時に 抢ける I-V波間潜時（嘼準偏差）では，30才 代之50才代，80才以上と50才代，60才代におい て $5 \%$ の危険率で有意着が涩められた。

原因疢蜆之 $\mathrm{I}-\mathrm{V}$ 波閒潜時の関係について は, 図 2 の如く脳内出响での $I-V$ 波閒潜洔

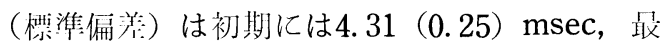
終時期には4.22（0.25） msec であった。同椂 に㹬膜下出利4.32(0.4) $\mathrm{msec}, 4.22(0.25)$ $\mathrm{msec}$, クモ膜下出帖 $4.46(0.47) \mathrm{msec}, 4.39$
(0.43) msec, 脳挫傷 $4.18(0.53) \mathrm{msec}, 4.08$ (0.37) msec, DOA4.53(0.53) msec, 4.8 (0.58) $\mathrm{msec}$ であった. DOAの潜洔は他の 原因に比して延長しており，最終测定時におい てDOAと脳挫傷の間に危険率 $5 \%$ で有意差が 認められた。しかし，他の原因疾患とは有意差 は認められなかった。

予後とAB R I - V 波間潜時との関係をみる 之, 回復例の初回平均 $\mathrm{I}-\mathrm{V}$ 波間潜時（標準 偏差）は4.19（0.37） msec，最終測定時4.14 (0.31) msec と I - V 波間潜時は終始正常範 囲内であった。植物移行例では，初回には 4.53 （0.57） msec と高度延長を示したが経過と共 に潜时が短維し最終测定時には4.27（0.27） msec となった。 これに反し死亡例では, 逆に 初问には4.38（0.4） msec であったものが最 終测定将には4.56（0.53） msec とさらに潜狩 の延長を呈した。統計学的検索に扔いては, 条 群の初问测定 A B R と最終测定待A B R との間

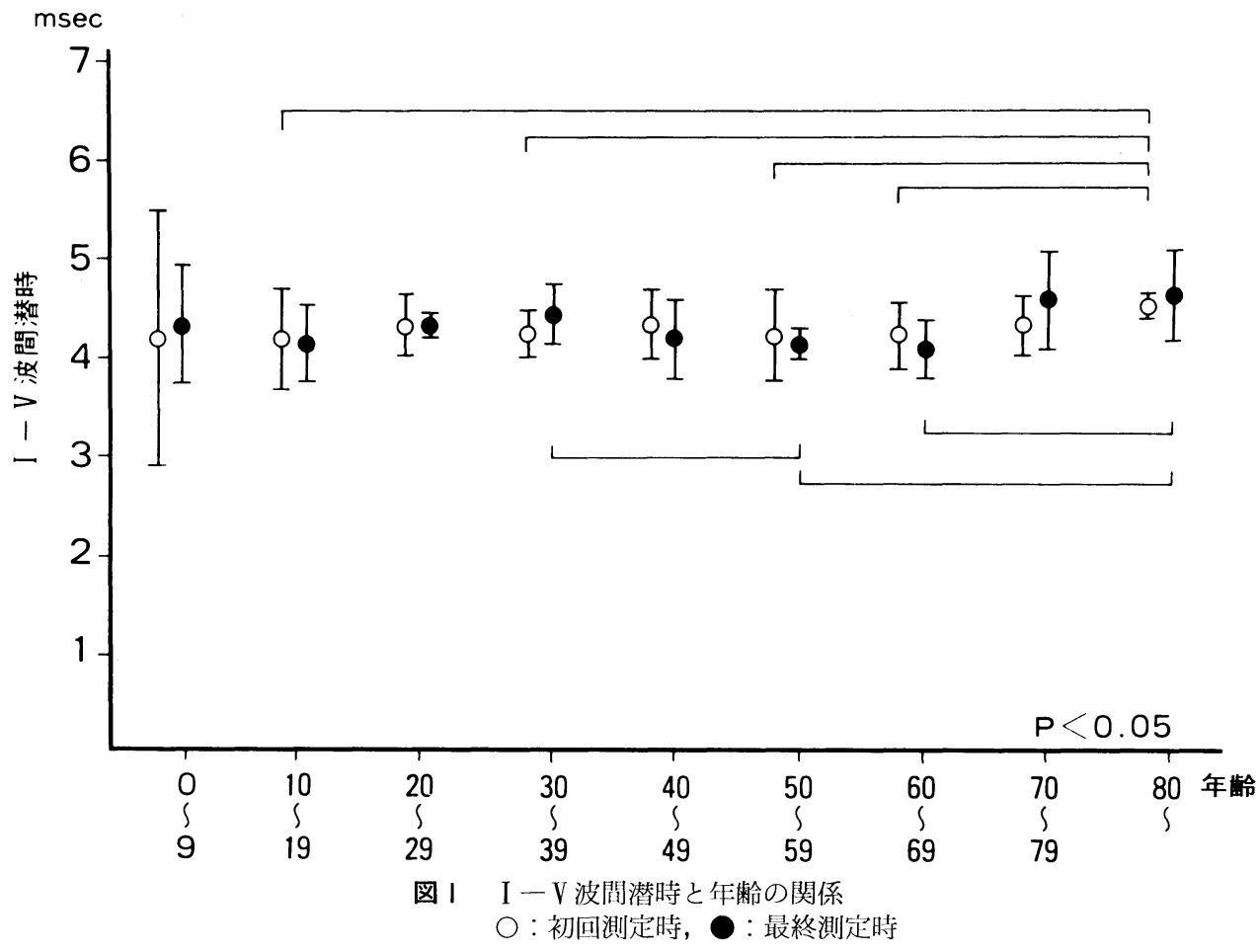


には，有意差は認められなかった，しかし，初 回ABRにおいて回復例之楒物例, 回復例之死

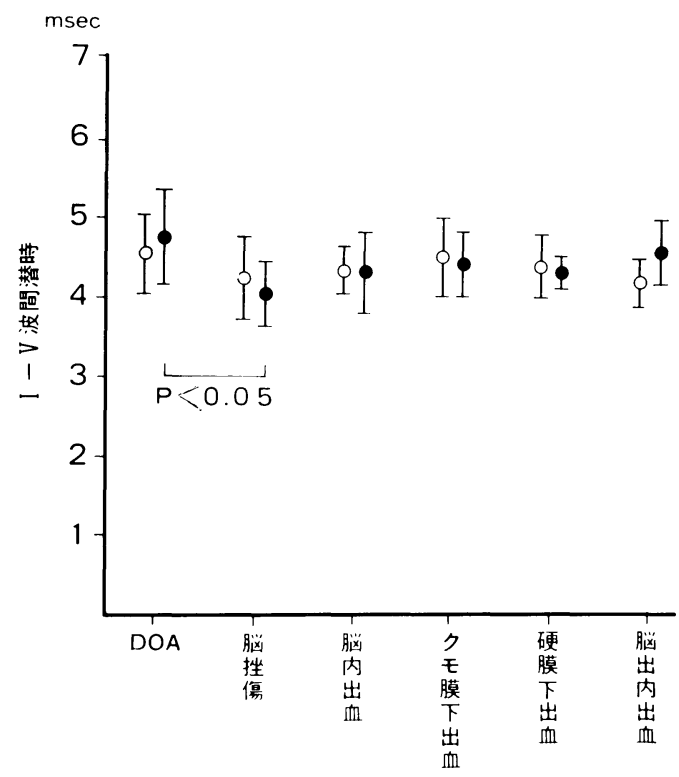

図 2 原因疾患による $\mathrm{I}-\mathrm{V}$ 波間潜時の違い $O$ : 初回測定時, ○：最終測定時

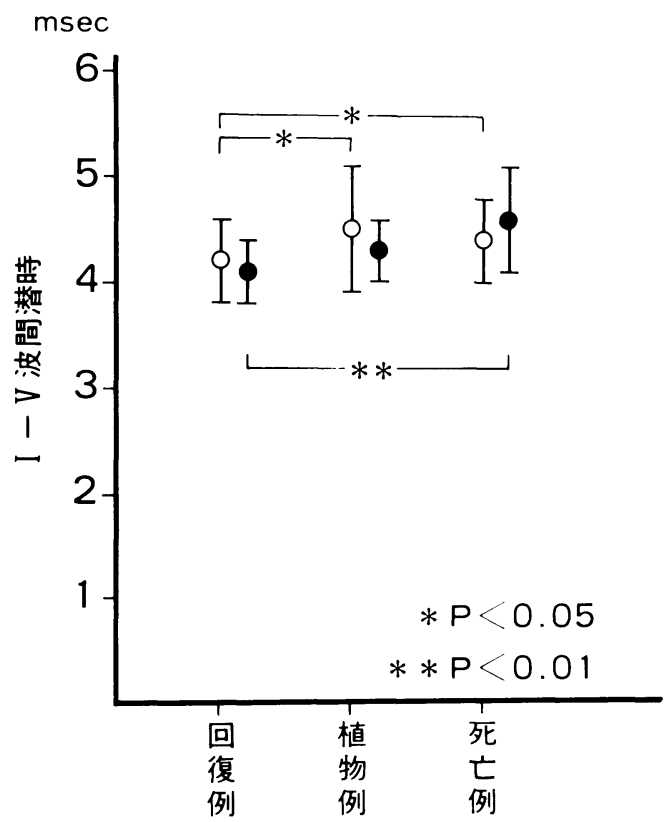

図 $3 \mathrm{I}-\mathrm{V}$ 波間潜時と予後の関係 $\bigcirc$ : 初回測定時, ○：最終測定時
亡例の間に $5 \%$ の危険率‘で有意差が認められ た。また，最終測定時には回復例之死亡例の間 に $1 \%$ 危険率で有意差が認められた（図 3 ). また，経時的にABRを測定したものと経過が 短時間であった為に 1 回しか測定できなかった 症例を比べると図 4 の如く 1 回のみの測定例 では, 回復例 $(4.27 \pm 0.36)$ 之死亡例 $(4.65 \pm$ 0.4）の間に $5 \%$ の危険率で有意差が認められ た。 また, 死亡例においては, 経時的に测定し たものの潜時 (4.32 00.4$)$ と 1 回のみの測定 症例の間に $5 \%$ 危険率で有意差が認められ た.

\section{考察}

Sohmer \& Feinmesser ${ }^{6)}$ ¿ Jewett ${ }^{7 / 8)} ら$ の報告以来 A B R は，他覚的聴力検査として広 く用いられている ${ }^{910)}$. また, その起源が脳幹 に由来するため脳幹機能検査として神経学的に 灾用されている. A B Rは, 意識状態や麻酔な どには，ほとんど影響を受けず安定した反応で あるため, 意識障㫪者の経過観祭や予後判定の

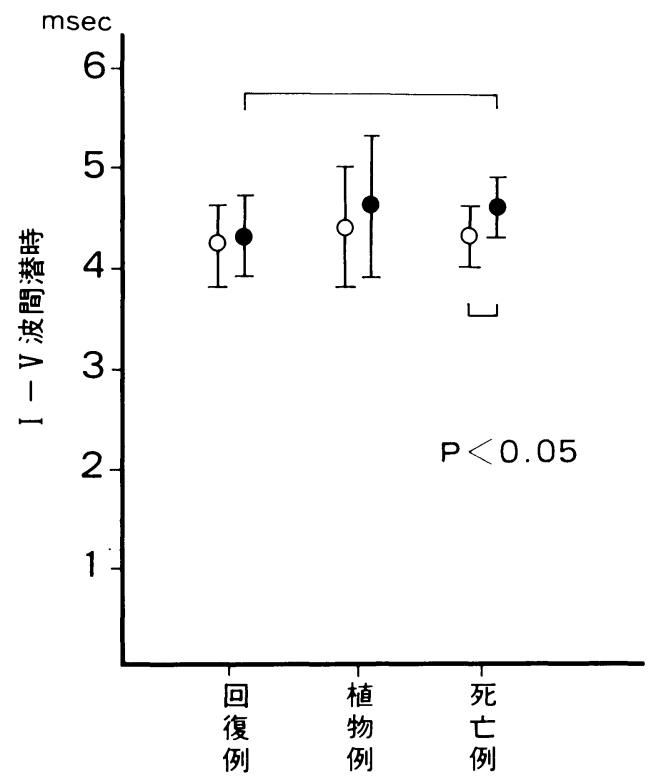

図 4 長期観察例と短期観察例の $\mathrm{I}-\mathrm{V}$ 波問潜時と予後

$\bigcirc$ : 経過観察例，○：測定が 1 回のみの例 
ために本反応を利用した報告が最近なされてい

る. しかし, 年齢, 性や体温の変化により A B Rの潜時に影響を受けることが知られてい

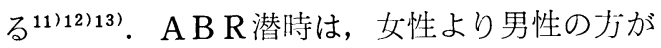
延長し，年齢が高くなるに連れて潜時が延長す ると報告されている，今回の，昏睡患者の年粭 とA B Rの検討では, 初回測定時に80才代と 10 才代，30才代，50才代，60才代に統計学的有意 差が認められたが，他の年代間には有意の差は 認められなかった. しかし，80才代における有 意差は, 症例が 3 例と少数であったためのあの と思われる. また，最終測定時において，30才 代と50才代の間に有意差が認められたが30才代 での死亡が 15 例中 5 例, 50 才代の死亡が 30 例中 21例之养があり予後の運いが潜時に影響したも のと思われ，年秢による潜時への影脊はほとん どみられなかった。乙れは，今回の症例が，ほ とんど男性であったとと，20才代から60才代に 症例が集中していたととによるものと思われ る.また，頭蓋の大きさがA B R の潜恃や振幅 に影響するとの川泪 ${ }^{14)} ら の$ 報告むあり今後, 年 齢や性养に加え頭蓋の大きさや頭皮の浮腫の状 態などを合せて検討する必要性があると考えら れる.

昏睡に陥った原因と患者の年澮分死では， 20 才代から60才代の男性が多く, その原因として 交通外傷や転落事故などによる頭部外傷や頭蓋 内出血がほとんどであった，乙のととは，働き 盛りの男性が最む事故に遭遇する危険性が高い ことを物語っている。一方, 10 才以下では DO Aが多く，その原因は漡れによるものが大部分 であったまた，70才代においてもDOAが多 く認められたが，原因として気洋閉寒によるも のがほとんどであった。

A B R と原因疾患との検钶では, DOAと脳 挫傷の最終測定時に有意差が認められたが，こ れはDOAでは，ほとんどの症例が死亡したの に対し脳挫傷では, ほとんどの症例が回復し, 予後の違いによる差と思われた。 また, 他の原

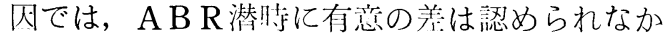

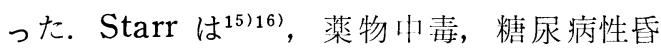
睡, 尿毒性氐睡, 肝性昏睡の A B R を検討し, これらの昏睡が A B R の潜時や振幅に影響を与 えないと報告している. 今回の検討では，原因 疾患は異なるが, Starr の結果と一致してお り，昏睡の原因による潜時への影蝗は無いもの と考えられた。

ABRと予後との関係については, Seales $ら^{17)}$, 馬場 ${ }^{18}$, Yagi $ら^{191}$, 長井 ${ }^{20)}$ の報告が あり，ABRを経時的飞観察し，A B R 波形が 覀化し I 波のみや無反応になる例は予後不良で あり，A B R は意識障害者の予後を判定する上 に有用な検査であると述べている．今回の検討 では, 初回測定時において, 回復例, 植物例, 死亡例の I-V波間潜時にそれぞれ有意差が認 められた。経侍的な観察でも，回復例と植物例 では, 徐々に潜時が短縮し, 死亡例では逆に潜 時が延長し, 回復例之死亡例の間に最終測定時 $\mathrm{I}$ - V 波間潜時に有意差が認められた。また， 初回測定時に波の火損や無反応であった症例 は, 全例死亡した。経時的に, 波形が消失し I 波のみや無反応に移行した症例も全例が死亡し た.とのととは, 初回の ABR 波形や潜時か ら，ある程度予後が予測されるが，ABRの経 過推察により，より正確な予後を判定すること が可能であると考えられる.

\section{まとめ}

昏睡患者 157 例の A B R を観祭し年齢，原因 疾患之の検討を行い合せて予後との関係をみ た.その結果，年歯および原因疾患による，A B Rの変化は認められなかった．経過と予後と の関係では, 回復例, 植物例においては, I一 $\mathrm{V}$ 波間潜時が経過亡共に短縮し，逆に死亡例で は, 経過と共に潜時の延長を認めた。 また, 初 回より波形が琹化している例や経過と共に波形 が悪化した例は全例死亡した. 以上のことか ら，ABRは昏睡患者の予後を判定するために 必要な検査であると考えられた。 


\section{文献}

1) Uziel A and Benezech J : Auditory brainstem responses in comatose patients; Relationship with brain-stem reflexes and level of coma. Electroenceph Clin Neurophysiol $45: 515 \sim 524,1978$.

2 ) Stockard JJ, et al : Nonpathologic factors influencing brain stem auditory evoked potentials. Am J EEG Technol 18:177 209, 1978.

3 ）八木聰明，他：昏睡患者の聴性脳幹反応と脳還流 圧. 耳鼻臨床 $79: 465 \sim 471,1986$.

4) Starr A : Auditory brain-stem responses in brain death. Brain $99: 543 \sim 554,1976$.

5 ) 馬場俊吉, 他：昏睡患者の脳波之聴性脸幹反応一 聴性脳幹反応による脳死の判定一. 脳神経 36 ： $6 ; 595 \sim 600,1984$.

6 ) Sohmer $\mathrm{H}$ and Feinmesser $\mathrm{M}$ : Cochlear and cortical audiometry. Conveniently recorder in the same subjects. Israel J Med Sci 6 : 219 223, 1970.

7 ) Jewett DL : Volume-conducted potentials response to auditory stimuli as detected by averaging in the cat. Electroenceph Clin Neurophysiol $28: 609 \sim 618,1970$.

8 ) Jewett DL et al : Auditory-evoked far fieIds averaged from the scalp of humans. Brain $94: 681 \sim 696,1971$.

9 ) Kodera $K$, et al : Brain stem response audiometry at speech frequencies. Audiology 16 : 469 479, 1977.

10）八木聰明, 馬場俊吉：A B R 異常と純音聴力検 查の関係について. 耳鼻臨床 $77: 381 \sim 387$, 1984.

11) Kjaer $M$ : Differences of latencies and amplitudes of brain stem evoked potentials in subgroups of a normal material. Acta Neurol Scandinav $59: 72 \sim 79,1979$.
12) Rowe MJ : Normal variability of the brainstem auditory evoked response in young and old adultsubjects. Electroenceph Clin Neurophysiol $44: 459 \sim 470,1978$.

13) Kaga $\mathrm{K}$ et al : Effects of deep hypothermia and circulatory arrest on the auditory responses. Arch Otorhinolaryngol 225:199 205, 1979.

14）山口 潤, 他：A B R と頭蓋の大きさとの関係. Audiology Japan 29: 5 ; 421 422, 1986.

15) Starr A and Achor LJ : Auditory brain stem responses in neurological disease. Arch Neurol $32: 761 \sim 768,1975$.

16) Starr A and Humilton AF : Correlation between confirmed sites of neurological lesions and abnormalities of farfield auditory brainstem responses. Electroenceph Clin Neuroph $41: 595 \sim 608,1976$.

17) Seales DM et al : Brainstem auditory evoked responses in patients comatose as a result of blunt head trauma. The Journal of Trauma 19:5;347 353, 1979.

19）馬場俊吉：昏睡患者の脳幹機能 と予後一聴性脳 幹反応と温度眼振反応を指標として一. 日耳鼻 $84: 1542 \sim 1553,1981$.

19) Yagi $T$ and Baba $S$ : Evaluation of the brainstem function by the auditory brain-stem response and the caloric vestibular reaction in comatose patient. Arch Otorhinolaryngol $238: 33 \sim 43,1983$.

20）長井大二, 他：急性意識障害例の聴性誘発反応 （A B R，ML C，S V R）による障害の程度と 分類と予後. 日耳鼻 $86: 1377 \sim 1383,1983$.

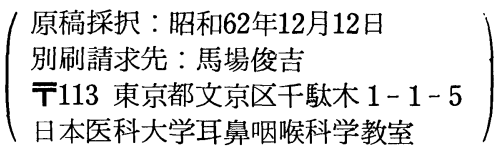

